ORIGINAL ARTICLE

\title{
Semen parameters in male partners of sub-fertile couples.
}

\author{
Asim Iqbal Qureshi' ${ }^{1}$, Tehreem Rasheed ${ }^{2}$, Ayesha Munir ${ }^{3}$, Taqwa Firdous ${ }^{4}$, Maria Khan ${ }^{5}$, Shazia Shafi ${ }^{6}$
}

Article Citation: Qureshi Al, Rasheed T, Munir A, Firdous T, Khan M, Shafi S. Semen Parameters in male partners of Sub-Fertile Couples. Professional Med J 2022; 29(1):53-56. https://doi.org/10.29309/TPMJ/2022.29.01.6540

\begin{abstract}
Objective: To evaluate the frequency of semen parameters in male partners of in sub-fertile couples. Study Design: Cross-sectional study. Setting: Department of Gynaecology, Bakhtawar Ameen Hospital, Multan. Period: July 2019 to July 2020. Material \& Methods: Infertile couples from at least 12 months were selected for study. A team of Gynaecologist, andrologist and endocrinologist assessed the couples. In male partner, general physical examination, endocrine factor, genetic assessment, accessory gland infection and testicular dysfunction were evaluated. Semen sample was sent to laboratory for semen analysis. Results: In a total of 169 sub-fertile couples, the mean age of male and female partner were $37.98 \pm 4.54$ years and $32.51 \pm 3.78$ years respectively. Mean duration since marriage was $5.17 \pm 4.51$ years. Abnormal semen parameters such as azoospermia, oilgo-azoospermia, asthenozoospermia, teratozoospermia and aspermia were noted 21 (12.4\%), 26 (15.4\%), 48 (28.4\%), 18 (10.7\%) and $10(5.9 \%)$ subjects respectively. There were 46 (27.2\%) subjects with normal semen parameters. Conclusion: Most of the male sub-fertile subjects had asthenozoospermia. More than one fourth of the subjects had normal semen parameters.
\end{abstract}

Key words: $\quad$ Azoospermia, Semen Analysis, Sub-Fertility.

\section{INTRODUCTION}

A common clinical problem in male is subfertility that affects about $15 \%$ of couples in world. ${ }^{1}$ Furthermore, subfertility is taken as serious public problem because of its association with many domestic issues. ${ }^{2}$ Beyond the couples life, subfertility also affects the social life of a person and its surroundings. Male subfertility factor is responsible for $20 \%$ infertile couples. ${ }^{3} \mathrm{~A}$ subfertile male always means an abnormal or subnormal semen analysis. Most probably clinicians rely on semen analysis to label or diagnose status of a male fertility. ${ }^{4}$

In clinical practice, semen analysis and measurement of semen parameters are surrogate measures for assessment of fertility. ${ }^{5}$ There is not too much consensus that which parameter of analysis is better predictor of fertility. In previous studies, a close correlation was reported between sperm count and pregnancy with evidence of sperm count values before and after conception. Sperm count along with sperm morphology and motility are also considered as male fertility predictors. ${ }^{6}$

Since WHO recommended reference values for semen parameters highlighting that semen analysis is sufficient to label male fertility status. ${ }^{7}$ Previous WHO values were recommended for healthymenornormal population notforpopulation of fertile men. Some serious concerns have been raised because of possibility of conceiving with below cutoff values recommended by WHO. It is a challenge for clinicians to determine which semen parameters of test have ability to predict male fertility or subfertility. ${ }^{8}$ This difficult situation leads to the inappropriate diagnosis, inaccurate treatment and depression for patients. ${ }^{9}$ Accurate diagnosis of subfertility could reduce the assisted reproduction in community. Some additional sperm tests such as eosine / swelling test are not
1. MBBS, FCPS (Obs \& Gyne), Assistant Professor Obs \& Gyne, Bakhtawar Ameen Hospital, Multan. 2. MBBS, FCPS (Obs \& Gyne), Senior Registrar Obs \& Gyne, Bakhtawar Ameen Hospital, Multan. 3. MBBS, FCPS (Obs \& Gyne), Woman Medical Officer Population Welfare, Nishtar Hospital, Multan. 4. MBBS, FCPS (Obs \& Gyne), Senior Registrar Obs \& Gyne, Bakhtawar Ameen Hospital, Multan. 5. MBBS, FCPS (Obs \& Gyne), Senior Registrar Obs \& Gyne, Bakhtawar Ameen Hospital, Multan. 6. MBBS, FCPS (Obs \& Gyne), Women Medical Officer Primary and Secondary Health, Women Prison Multan.

\author{
Correspondence Address: \\ Dr. Ayesha Munir \\ Population Welfare \\ Nishtar Hospital, Multan. \\ drayesha60@gmail.com
}

Article received on: Accepted for publication:
$17 / 04 / 2021$

$24 / 06 / 2021$ 
sufficient to provide information to label fertility status. ${ }^{10}$ This study was conducted to evaluate the frequency of abnormal semen parameters in sub-fertile patients.

\section{MATERIAL \& METHODS}

This cross sectional study was conducted in Gynaecology Department of Bakhtawar Ameen Hospital, Multan from July 2019 to July 2020. Study was started after obtaining ethical approval from hospital ethical board and written informed consent was taken from subjects. Adopting nonprobability consecutive sampling technique, a total of 169 infertile couples from at least 12 months were enrolled. A team of gynaecologist, andrologist and endocrinologist assessed the couples. General physical examination, cervical and vaginal infection screening, hormonal assessment of ovulatory morphology, tubal patency evaluation, transvaginal scan and assessment of genetics were carried for female partners. In male partners, general physical examination, endocrine factor, genetic assessment, accessory gland infection and testicular dysfunction were evaluated.

Semen analysis was ordered and assessed according to WHO guidelines. Patients were also classified according to predictor value of pregnancies such as asthenospermia, oligospermia, teratospermia and oligoasthenoteratospermia. Semen findings in subfertile men were categorized as normal (normal semen values according to WHO standards); azoospermia (no spermatozoa in the ejaculate);

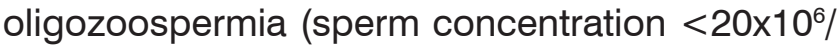
$\mathrm{ml}$ ); asthenzoospermia ( $<50 \%$ motile sperm); oligoasthenozoospermia (including both criteria).

Men with identified infertility were treated etiologically but subfertile patients were treated empirically (antioxidants, gonadotropins, aspartic acid and carnitine). SPSS version 26.0 was used for data analysis. Mean $\pm S D$ were calculated for numerical variables like age, duration since marriage while frequency and percentages were calculated for categorical variables like abnormal semen parameters.

\section{RESULTS}

In a total of 169 sub-fertile couples, the mean age of male partner was $37.98 \pm 4.54$ years. The mean age of female partners was $32.51 \pm 3.78$ years. Mean duration since marriage was $5.17 \pm 4.51$ years. There were $95(56.2 \%)$ couples who belonged to rural areas of residence while remaining 74 (43.8\%) were from urban areas. Table-I is showing characteristics of patients.

\begin{tabular}{|l|c|}
\hline \multicolumn{1}{|c|}{ Characteristics of Patients } & Mean+SD \\
\hline Age of male partner (years) & $37.98 \pm 4.54$ \\
\hline Age of female partner (years) & $32.51 \pm 3.78$ \\
\hline BMl of Male Partner $\left(\mathrm{kg} / \mathrm{m}^{2}\right)$ & $25.48+2.14$ \\
\hline BMl of Male Partner $\left(\mathrm{kg} / \mathrm{m}^{2}\right)$ & $24.57+2.40$ \\
\hline Duration since marriage (years) & $5.17 \pm 4.51$ \\
\hline
\end{tabular}

Table-I. Characteristics of the patients.

Table-Il shows semen parameter classifications amongmalepartners. Abnormalsemenparameters such as azoospermia, oilgozoospermia, asthenozoospermia, teratozoospermia and aspermia were noted 21 (12.4\%), 26 (15.4\%), 48 (28.4\%), 18 (10.7\%) and 10 (5.9\%) subjects respectively. There were $46(27.2 \%)$ subjects with normal semen parameters.

\begin{tabular}{|l|c|}
\hline \multicolumn{1}{|c|}{ Semen Parameter Classifications } & Number (\%) \\
\hline Normospermia & $46(27.2 \%)$ \\
\hline Azoospermia & $21(12.4 \%)$ \\
\hline Oilgozoospermia & $26(15.4 \%)$ \\
\hline Asthenozoospermia & $48(28.4 \%)$ \\
\hline teratozoospermia & $18(10.7 \%)$ \\
\hline Aspermia & $10(5.9 \%)$ \\
\hline \multicolumn{2}{|c|}{ Table-II. Semen parameter classifications. (n=169) } \\
\hline
\end{tabular}

\section{DISCUSSION}

Worldwide sub fertility is a common health condition affecting approximately $15 \%$ of couples and among them male factor contributing $50 \%$ of cases. ${ }^{11}$ Abnormal semen parameters such as azoospermia, oilgozoospermia, asthenozoospermia, teratozoospermia and aspermia were noted 21 (12.4\%), 26 (15.4\%), 48 (28.4\%), 18 (10.7\%) and 10 (5.9\%) subjects respectively. Latest intervention and analysis questioned the $\mathrm{WHO}$ recommended values of 
semen analysis in prediction of fertility. In a study conducted by Milardi et al $^{12}$ in 2012 reported that $65 \%$ of cases in his study acquired spontaneous conception with semen analysis parameters below WHO reference values. Among these 65\% of cases $26 \%$ had reduced sperm count, $27 \%$ had oligspermia. Zinaman et $\mathrm{al}^{13}$ also conducted a similar study on this topic and reported identical findings about WHO reference values and spontaneous conception of oligospermic condition in their study. In that study, 210 reproductive couples were observed who were unaware of their low semen quality but spending a successful fertile life. Guzick et $\mathrm{al}^{14}$ reported in their study that sperm morphology, motility and concentration can be used to identify male sub fertility, indeterminate fertility and fertility but infertility is not a condition of sperm parameters.

In contrast with studies given above Ombelet et al ${ }^{15}$ reported in his study a strong correlation between abnormal or subnormal semen parameters and male subfertility. They observed a shift of seminal statistics toward sub normality in subnormal male. Five percent of cases showed abnormality in sperm morphology and $28 \%$ in sperm motility. Bonde et $\mathrm{al}^{16}$ observed that some male have semen parameters above than $\mathrm{WHO}$ cut off values but they are subfertile which shows that subfertility is not associated with seminal parameters. Literature also shows that subfertility or infertility mostly occurred due to infection in male that leads to the asthenospermia. Teratospermia in fact does not affect the spontaneous conception. Reduction in sperm morphology was observed in fertile men that means only moderate predictive value for spontaneous conception is sufficient. ${ }^{17}$ Zaini et $\mathrm{al}^{18}$ concluded that sperm morphology is not important and useful factor in prediction of infertility in sub fertile male but sperm count of 5 million per $\mathrm{ml}$ and good sperm motility are important predictors in oligospermic male.

Pasqualotto et $\mathrm{al}^{19}$ and Hirsh et $\mathrm{al}^{20}$ reported in their studies that WHO cut off values of semen parameters to predict subfertility needs to be reconsidered. Sperm morphology (strong predictor of fertilizing capacity) may be found abnormal due to excessive intercourse, infection in male genital tract. A rare cause of male subfertility is endocrine deficiency. van der Merwe et al ${ }^{21}$ conducted a study on subfertile male and semen parameters and concluded that sperm motility $<30 \%$, morphology $<5 \%$ and concentration $<15$ $\times 106 / \mathrm{ml}$ should be recommended to identify subfirtile male. Semen parameters in combination increase the importance of semen analysis in clinical field. Günalp et $\mathrm{al}^{22}$ calculated a lower threshold of $5 \%$ as positive predictive value in indication of subfertility in male population.

\section{CONCLUSION}

Most of the male sub-fertile subjects had asthenozoospermia. More than one fourth of the subjects had normal semen parameters.

Copyright $@ 24$ June, 2021.

\section{REFERENCES}

1. Ghasemi B, Mosadegh MA, Jones C, Ghasemi N. Semen analysis of subfertility caused by testicular carcinoma. Int J Reprod Biomed. 2020; 18(7):539-50.

2. Robert B, Maja B, Katušić BA, Monika U, Maja V, Davor $\mathrm{J}$, et al. Epigenetics and testicular germ cell tumors. Gene. 2018; 661:22-33.

3. Agarwal A, Dias TR, Pushparaj PN, Ahmad G, Sharma $R$. Alterations in the expression of sperm proteins affect fertility of patients with testicular cancer seminoma. Fertil Steril. 2018; 110(4):e167.

4. Abayomi BA, Afolabi BM, Victor DA, Oyetunji I. Semen parameters associated with male infertility in a subsaharan black population: The effect of age and body mass index. J Gynecol Infertility. 2018; 1(1):1-6.

5. Majzoub A, Agarwal A, Cho CL, Esteves SC. Sperm DNA fragmentation testing: A cross sectional survey on current practices of fertility specialists. Transl Androl Urol. 2017; 6(Suppl 4):S710-S719.

6. Guo D, Wu W, Tang Q, Qiao S, Chen Y, Chen M, et al. The impact of BMI on sperm parameters and the metabolite changes of seminal plasma concomitantly. Oncotarget. 2017; 8(30):48619-48634.

7. Andersen JM, Rønning PO, Herning $\mathrm{H}$, Bekken SD, Haugen TB, Witczak O. Fatty acid composition of spermatozoa is associated with BMI and with semen quality. Andrology. 2016; 4(5):857-865. 
8. Tang WH, Zhuang XJ, Ma LL, Qiao J, Hong K, Zhao L, et al. Correlation between body mass index and semen quality in male infertility patients. Turk J Med Sci. 2015; 45(6):1300-5.

9. Sharma R, Ahmad G, Esteves SC, Agarwal A. Terminal deoxynucleotidyl transferase dUTP nick end labeling (TUNEL) assay using bench top flow cytometer for evaluation of sperm DNA fragmentation in fertility laboratories: Protocol, reference values, and quality control. J Assist Reprod Genet 2016; 33:291-300.

10. Wiweko $B$, Utami $P$. Predictive value of sperm deoxyribonucleic acid (DNA) fragmentation index in male infertility. Basic Clin Androl 2017; 27:1.

11. Whitman-Elia GF, Baxley EG. A primary care approach to the infertile couple. J Am Board Fam Pract. 2001; 14(1):33-45.

12. Milardi D, Grande G, Sacchini D. Male fertility and reduction in semen parameters: A single tertiarycare center experience. Int J Endocrinol. 2012; 2012:649149.

13. Guzick DS, Overstreet JW, Factor-Litvak P. Sperm morphology, motility, and concentration in fertile and infertile men. N Engl J Med. 2001; 345(19):1388-1393.

14. Zinaman MJ, Brown CC, Selevan SG, Clegg ED. Semen quality and human fertility: A prospective study with healthy couples. J Androl. 2000; 21(1):145-153.

15. Ombelet $\mathrm{W}$, Bosmans $\mathrm{E}$, Janssen $\mathrm{M}$, Vlasselaer J, Gyselaers Ww, Vandeput $\mathrm{H}$, et al. Semen parameters in a fertile versus subfertile population: A need for change in the interpretation of semen testing. Hum Reprod. 1997; 12(5):987-993.
16. Bonde JP, Ernst E, Jensen TK, Hjollund NH, Kolstad H, Henriksen TB, et al. Relation between semen quality and fertility: A population-based study of $\mathbf{4 3 0}$ firstpregnancy planners. Lancet. 1998; 352(9135):11721177.

17. Sripada S, Townend J, Campbell D, Murdoch L, Mathers E, Bhattacharya S. Relationship between semen parameters and spontaneous pregnancy. Fertil Steril. 2010; 94(2):624-630.

18. Zaini A, Jennings MG, Baker HW. Are conventional sperm morphology and motility assessments of predictive value in subfertile men? Int J Androl. 1985; $8(6): 427-435$.

19. Hirsh A. Male subfertility. BMJ. 2003; 327(7416):66972.

20. Pasqualotto FF, Sobreiro BP. High percentage of abnormal semen parameters in a prevasectomy population. Fertility and Sterility. 2006; 85(6):954-60.

21. Van der Merwe FH, Kruger TF, Oehninger SC, Lombard $\mathrm{CJ}$. The use of semen parameters to identify the subfertile male in the general population. Gynecol Obstet Invest. 2005; 59(2):86-91.

22. Menkveld R, Wong WY, Lombard CJ, Wetzels AM, Thomas CM, Merkus HM, et al. Semen parameters, including WHO and strict criteria morphology, in a fertile and infertile population: An effort towards standardization of in-vivo thresholds. Hum Reprod 2001; 16: 1165-71.

\begin{tabular}{|c|c|c|c|}
\hline \multicolumn{4}{|c|}{ AUTHORSHIP AND CONTRIBUTION DECLARATION } \\
\hline No. & Author(s) Full Name & Contribution to the paper & Author(s) Signature \\
\hline 1 & Asim Iqbal Qureshi & Introduction, Proof reading. & Asimqus \\
\hline 2 & Tehreem Rasheed & Data collection, Methodology. & Tanseem. Rnibed \\
\hline 3 & Ayesha Munir & Data analysis, Discussion. & Jays \\
\hline 4 & Taqwa Firdous & $\begin{array}{l}\text { Literature Review, Data } \\
\text { collection. }\end{array}$ & Taqua Ferdous \\
\hline 5 & Maria Khan & Drafting, References. & maria \\
\hline 6 & Shazia Shafi & $\begin{array}{l}\text { Data Collection, Final } \\
\text { approval. }\end{array}$ & \\
\hline
\end{tabular}

